\title{
Antimicrobial potential of Pediococcus acidilactici from Bekasam, fermentation of sepat rawa fish (Tricopodus trichopterus) from Banyuasin, South Sumatra, Indonesia
}

\author{
SRI MELIA ${ }^{1, \boldsymbol{}}$, ENDANG PURWATI ${ }^{1}$, YULIANTI FITRI KURNIA ${ }^{1}$, DHIVA REZZY PRATAMA ${ }^{2}$ \\ ${ }^{1}$ Faculty of Animal Science, Universitas Andalas. J1. Univ. Andalas, Limau Manis, Padang 25171, West Sumatra, Indonesia. \\ Tel.: +62-751-71464, Fax.: +62-751-71464. "srimelia75@ansci.unand.ac.id \\ ${ }^{2}$ Animal Science Graduate Program, Universitas Andalas. J1. Univ. Andalas, Limau Manis, Padang 25171, West Sumatra, Indonesia
}

Manuscript received: 7 October 2019. Revision accepted: 14 November 2019.

\begin{abstract}
Melia S, Purwati E, Kurnia Y. F, Pratama D. R. 2019. Antimicrobial potential of Pediococcus acidilactici from Bekasam, fermentation of sepat rawa fish (Tricopodus trichopterus) from Banyuasin, South Sumatra, Indonesia. Biodiversitas 20: 3532-3538. This study aimed to determine the antimicrobial potential of lactic acid bacteria isolated from bekasam. Bekasam is a result of sepat rawa fermentation from Banyuasin District, South Sumatra, Indonesia. The results showed that the morphological and biochemical properties of lactic acid bacteria were Gram-positive and cocci, negative catalase and included in homofermentative groups. The biggest antimicrobial activity was shown by bekasam isolate to Escherichia coli O157: H7 (21.26 mm), followed by Staphylococcus aureus ATCC25923 $(18.23 \mathrm{~mm})$ and Listeria monocytogenes CFSAN004330 $(5.10 \mathrm{~mm})$, while diameter barriers for crude bacteriocin supernatant isolates lactic acid bacteria to Escherichia coli O157: H7, Staphylococcus aureus ATCC25923 were $14.99 \mathrm{~mm}, 17.69 \mathrm{~mm}$, and Listeria monocytogenes CFSAN004330 had no antimicrobial activity at neutral $\mathrm{pH}$. The results of molecular identification with $16 \mathrm{~S}$ rRNA showed that lactic acid bacteria isolated from bekasam isolate have similarity with Pediococcus acidilactici strain PB22 that has antimicrobial potential against pathogenic bacteria and potential as bio preservatives.
\end{abstract}

Keywords: Antimicrobial, bekasam, fermented fish, lactic acid bacteria, sepat rawa

\section{INTRODUCTION}

Traditional fermented natural food is very diverse in Indonesia because the territory of Indonesia is very wide and has distinctive food characteristics for each region one of them is curd. Curd is a natural fermentation of buffalo milk from West Sumatra that is beneficial for health (Surono 2003, 2009) and contains several types of lactic acid bacteria (Venema and Surono 2019). Lactococcus lactis ssp. lactis, L. plantarum ssp. plantarum, L. lactis ssp. cremoris, Pediococcus pentosaceus, and Lactobacillus pentosus are some types of bacteria that are naturally found in curd (Wirawati et al. (2019). Tempoyak, a natural fermentation product from Durian, is also a natural fermentation product (Juliyarsi et al. (2018) and tempoyak also contains lactic acid bacteria that have the potential as probiotics (Hartini et al. 2019 and Ahmad et al. 2018). In addition, there are also naturally occurring fish fermented products called Budu originating from West Sumatra. Lactic acid bacteria from Budu that have the potential as antimicrobial Bacillus cereus strain HVR22 (Yusra et al. (2013). All-natural fermentation product contains lactic acid bacteria that are very beneficial for health.

Bekasam is a traditional food originating from several regions in Indonesia such as Java, South Sumatra, and South Kalimantan. Bekasam is the result of spontaneous fermentation of fish. According to Desniar et al. (2013), Bekasam is used as a processed fish product by fermentation that tastes sour. Fish that can be used as exam is the type of freshwater fish. The raw material in the form of cork fish, beam, siam and swamp spikes with the addition of salt about $15-20 \%$, and added $15 \%$ sangria rice, then fermented for about one week to produce a distinctive aroma and taste.

There are several previous studies about the content of lactic acid bacteria in bekasam. Wikandari et al (2012), found lactic acid bacteria that have proteolytic activity namely Lactobacillus plantarum B765, L. plantarum T2565, L. plantarum N2352, L. plantarum B1465, L. pentosus B2555, and Pediococcus pentosaceus B1666. Desniar et al. (2013), in their study, revealed the presence of antimicrobial activity of lactic acid bacteria isolates to Staphylococcus aureus, which was caused by the ability of organic acids as antibacterial compounds. Then, Afriani et al. (2015) isolated lactic acid bacteria of bekasam from Jambi, which also had proteolytic activity, namely Lactobacillus pentosus BS15, L. plantarum $1 \mathrm{BS} 22$ and $L$. plantarum 1 BL12. Melia, et al. (2018), tested the antibacterial activity of lactic acid bacteria Bekasan against Staphylococcus aureus ATCC 25923, Escherichia coli ATCC 25922 and Salmonella sp. However, the previous researches do not provide the same type of fish that might be resulted in differences in microbial profiles compared to this study. This study will evaluate the potential of lactic acid bacteria from the fermented sepat rawa fish (Tricopodus trichopterus Pallas, 1770) that is a typical type of fish used in the Banyuasin region, which has antimicrobial 
activity and is a potential source bacteriocin, which can later be used as probiotic and biopreservative.

\section{MATERIALS AND METHODS}

\section{Bekasam Processing}

The process of making bekasam is very simple. The ingredients consist of fish, rice, and salt. The fish was cleaned, then added salt and rice sufficiently, put in a bottle and closed tightly. The bottle was stored at room temperature for 3 days (Figure 1).

\section{Sampling}

The material of this study was 4 bekasam samples originating from sepat rawa fermented fish obtained from four producers in Banyuasin, South Sumatra, Indonesia $\left(1,3^{\circ}-4^{\circ} \mathrm{S}, 103^{\circ}-105^{\circ}\right.$ E.) (Figure 2$)$, namely Pulau Harapan Village (Producer 1), Mainan Village (Producer 2), Sei Rengit Village (Producer 3) and Santan Sari Village (Producer 4). This location is a swampy area that produces lots of Sepat rawa fish.

\section{Isolation and Identification of Lactic Acid Bacteria}

The isolate of lactic acid bacteria from bekasam was cultured in broth De Man, Rogosa and Sharpe (MRS), broth media (Merck, Germany) and planted in MRS agar media (Merck, Germany) that was incubated at $37^{\circ} \mathrm{C}$ in an anaerobic jar for 48 hours. Furthermore, morphological properties (shape and color) were observed, and biochemical properties (Gram staining, catalase test and fermentation type) Phikunthong and Yunchalard (2010).

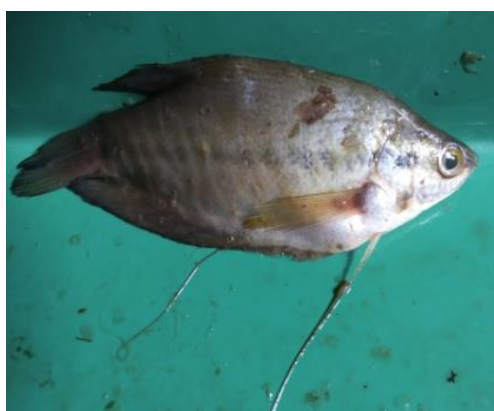

A

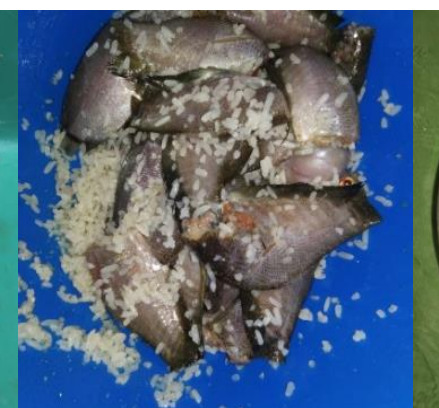

B

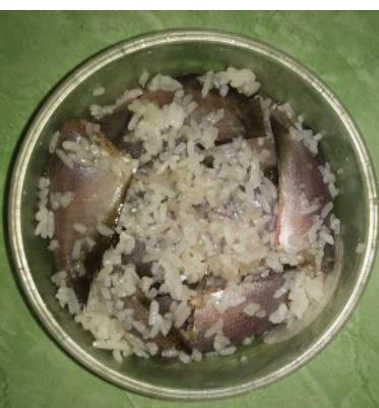

C

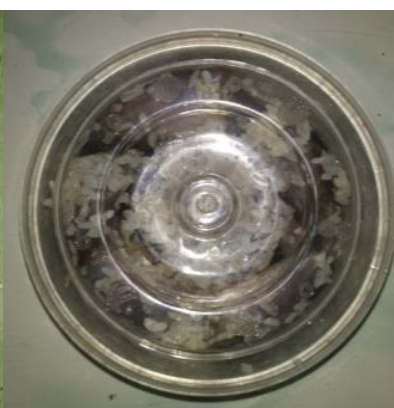

D

Figure 1. Bekasam processing: A. Clean sepat fish scales, B. Give salt and rice, C. Store in jar bottles, D. Bekasam is fermented for 3 days at room temperature

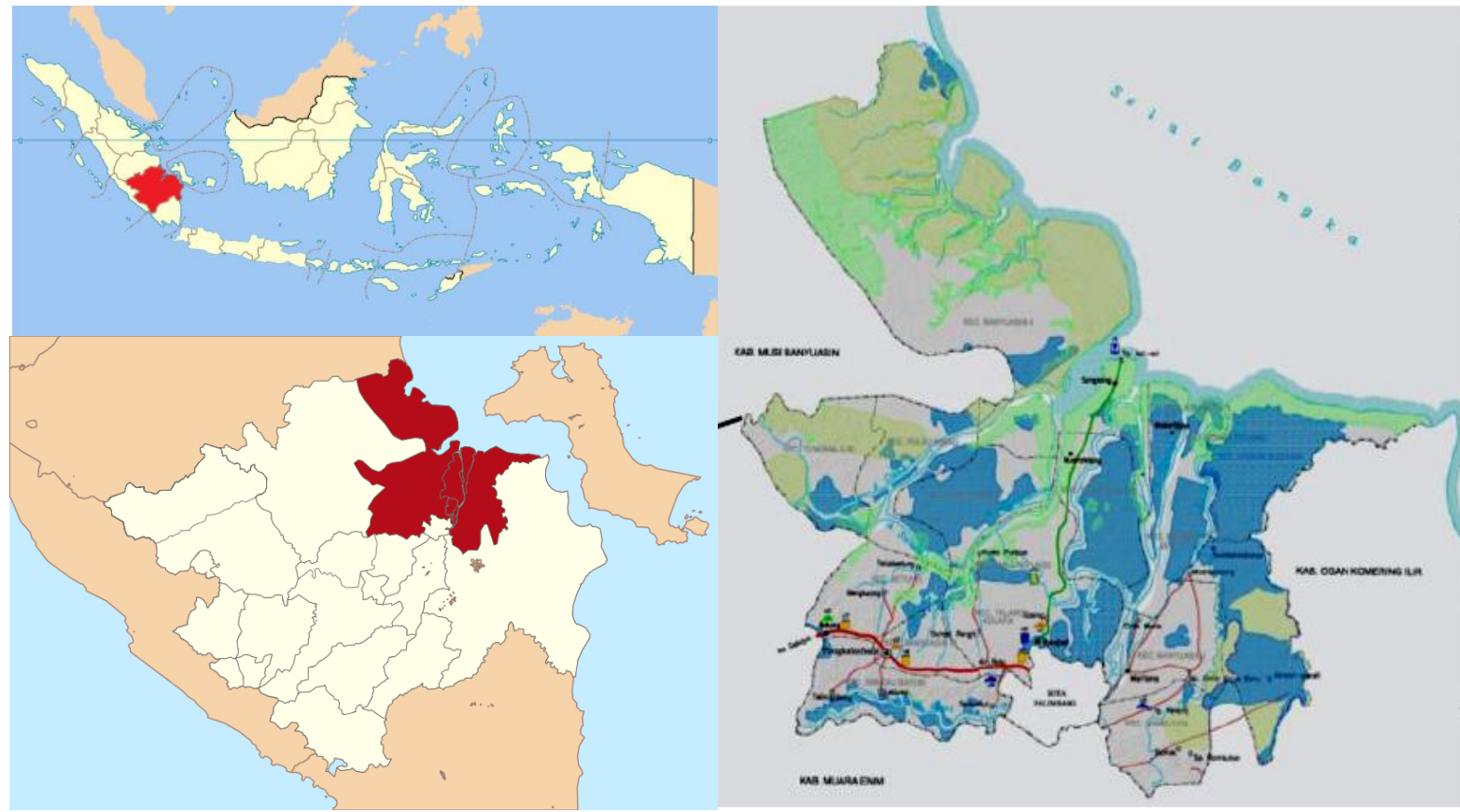

Figure 2. Study area in Banyuasin, South Sumatra, Indonesia $\left(1,3^{\circ}-4^{\circ} \mathrm{S}, 103^{\circ}-105^{\circ} \mathrm{E}\right)$ 


\section{Antimicrobial activity test}

Modification of the Yang et al. (2012) method was used for antimicrobial activity tests against pathogens. The method used was well diffusion assay. In short, cell-free supernatants were obtained from lactic acid bacteria grown in MRS Broth, for 24 hours at $37^{\circ} \mathrm{C}$, anaerobic conditions and centrifuged at $10,000 \mathrm{rpm}, 5$ minutes at $4^{\circ} \mathrm{C}$. A $50 \mu \mathrm{L}$ supernatant was inserted into a well $(6 \mathrm{~mm})$ that was perforated with a cork borer. Previously Nutrient Agar (Merck, Germany) has been grown by pathogenic bacteria. Pathogenic bacteria are grown aerobically at $37^{\circ} \mathrm{C}$ for 24 hours. Then $0.2 \%$ of pathogenic bacterial culture was added into Nutrient Agar. As a control, it was compared to antibiotics (penicillin $10 \mu \mathrm{g}$, kanamycin $30 \mu \mathrm{g}$, ampicillin $10 \mu \mathrm{g})$. The clear zone formed can be read after 24 hours.

\section{Antimicrobial test of crude bacteriocin supernatant}

One $\mathrm{ml}$ of culture was incubated for 24 hours in $9 \mathrm{ml}$ MRS broth for 24 hours at $37{ }^{\circ} \mathrm{C}$. Then centrifuged at $14,000 \mathrm{rpm}$ for 5 minutes. The supernatant was filtered with a $0.22 \mu \mathrm{L}$ membrane filter. Cell-free supernatant was regulated up to $\mathrm{pH} 6.5$ with $1 \mathrm{~N} \mathrm{NaOH}$ to eliminate the effect of barriers because of the presence of organic acids (Yang et al. 2012). Pathogenic bacteria were grown aerobically at $37^{\circ} \mathrm{C}$ for 24 hours. Then the pathogenic bacterial culture was $0.2 \%$ into $20 \mathrm{ml}$ of Muller Hinton Agar (MHA) at $50{ }^{\circ} \mathrm{C}$. After agar became solid, well was with a size of $6 \mathrm{~mm}$ using the cork borer. Then the supernatant was taken as much as $50 \mu \mathrm{L}$ and inserted into each well and allowed to stand for 15-20 minutes, then incubated for 24 hours at $37^{\circ} \mathrm{C}$ in aerobic conditions. The inhibitory zone was measured by using the caliper. If the well is found, the inhibition zone can be said to be BAL isolate that contains bacteriocin compounds.

\section{DNA genomes isolation of Lactic Acid Bacteria and 16S rRNA}

Lactic acid bacteria isolates were cultured in MRS broth at $37^{\circ} \mathrm{C}$ for $24 \mathrm{~h}$. Isolation of genomic DNA was carried out using Promega Kit (USA). Single colony lactic acid bacterial isolates from MRS Broth were piped as much as $1000 \mu \mathrm{L}$ and included in the new Eppendorf. Centrifuged as $14000 \mathrm{rpm}$ for 2 minutes. Then the supernatant is removed and the pellet is taken. Added with $480 \mu \mathrm{L} 50 \mathrm{mM}$ EDTA. Then, $120 \mu \mathrm{L}$ of Lysozyme was added. Next, Incubation in $37^{\circ} \mathrm{C}$ water bath for 60 minutes. Centrifuge for 2 minutes $14000 \mathrm{rpm}$, then remove the supernatant and pellet is taken. Added with $600 \mu \mathrm{L}$ nuclei lysis solution. Incubated $80^{\circ} \mathrm{C}$ for 5 minutes, then let it stand at room temperature. Added $3 \mu \mathrm{L}$ of RNase Solution, incubated in water bath $37^{\circ} \mathrm{C}$ for 60 minutes. Added with $200 \mu \mathrm{L}$ of the protein precipitation solution then vortex. $600 \mu \mathrm{L}$ of isopropanol was added. Centrifuged for 2 minutes $14000 \mathrm{rpm}$, then pellets are taken and the supernatant is removed. Added $600 \mu \mathrm{L}$ of ethanol $70 \%$ and then homogenized. Centrifuged for 2 minutes $14000 \mathrm{rpm}$, then pellets were taken and the supernatant was removed.
Pellet DNA rehydration by adding $10-100 \mu \mathrm{L}$ of Rehydration solution for 30 minutes at $65^{\circ} \mathrm{C}$. Primer $\mathrm{R}$ (16S-1492R, Tm $47^{\circ} \mathrm{C}$, 5'-GTT TAC CTT GTT ACT ACT- $\left.3^{\prime}\right)$ and $\mathrm{F}\left(16 \mathrm{~S}-27 \mathrm{~F}\right.$, Tm $54.3^{\circ} \mathrm{C}, 5^{\prime}$-AGA GTT TGA TCC TGG CTC AG-3'), prepared (concentration of 10 $\mathrm{pM}$ ). Take $90 \mu \mathrm{L} \mathrm{dH} 2 \mathrm{O}+10 \mu \mathrm{L}$ (Primary $\mathrm{R}$ and $\mathrm{F}$ ). (Primary R and F in TE buffer (concentration $100 \mu \mathrm{M}$ ). Cocktail PCR in1 Eppendorf (Master Mix 12.5 $\mu \mathrm{L}$, Primary F $1 \mu \mathrm{L}$, Primary R $1 \mu \mathrm{L}$, Template DNA $1 \mu \mathrm{L}$, ddH2O 9.5 $\mu \mathrm{L}$ ), with PCR denaturation $95^{\circ} \mathrm{C} 45$ seconds, annex $56^{\circ} \mathrm{C}$ 45 seconds, Extention $72^{\circ} \mathrm{C} 1$ minutes 40 seconds, final extention $72^{\circ} \mathrm{C} 10$ minutes. Electrophoresis of $10 \mu \mathrm{L}$ samples into the well agar, inserted $4 \mu \mathrm{L}$ of the DNA ladder. Set to $100 \mathrm{~V}$ for 45 minutes. The gel placed in a container plus TBE until submerged. The gel, then seen under the UV lamp. The 16S rRNA gene sequences of the isolate were submitted to the NCBI for a BLAST search. The MEGA version 6.0 (http://www.megasoftware.net) was used to create phylogenetic trees using the neighborjoining (NJ) method.

\section{RESULTS AND DISCUSSION}

\section{Morphological and biochemical characteristics of lactic acid bacteria isolate}

Fifty-six isolates of lactic acid bacteria were isolated from bekasam, morphologically round (cocci), rod-shaped, and cream-colored. The testing of biochemical properties showed that the results of Gram-positive and negative catalog as well as isolated of lactic acid bacteria were homofermentative as indicated by the absence of gas bubbles in the Durham tube. Desniar et al. (2013), also stated that in general, the LAB isolates from bekasam were homofermentative.

\section{Antimicrobial activity of Lactic Acid Bacteria isolate}

Of the fifty-six isolates of lactic acid bacteria, there were 4 isolates that had antimicrobial activity, but only bekasam isolates had antimicrobial activity against the three tested pathogenic bacteria, Escherichia coli O157: H7, Staphylococcus aureus ATCC25923 and Listeria monocytogenes CFSAN004330. Antimicrobial activity of bekasam isolates from bekasam on pathogenic bacteria, Escherichia coli O157: H7, Staphylococcus aureus ATCC25923 and Listeria monocytogenes CFSAN004330 can be seen in Table 1. Antibiotics used positive controls

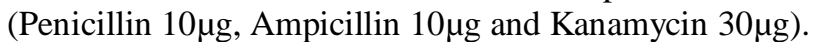

In Table 1, the largest antimicrobial activity was shown by bekasam isolate against $E$. coli O157: H7, with a clear zone diameter of $21.26 \mathrm{~mm}$ followed by $S$. aureus ATCC $2592318.23 \mathrm{~mm}$ and L. monocytogenes CFSAN004330 $5.10 \mathrm{~mm}$. LAB isolate, had greater antimicrobial activity against E. coli O157: H7 than the three antibiotics used, namely penicillin $10 \mu \mathrm{g}$, kanamycin $30 \mu \mathrm{g}$, ampicillin 10 $\mu \mathrm{g}$. 
Table 1. Antimicrobial activity bekasam isolate and antibiotic test

\begin{tabular}{|c|c|c|c|}
\hline \multirow[b]{2}{*}{ Inhibitory source } & \multicolumn{3}{|c|}{ Clear zone $(\mathrm{mm})$} \\
\hline & $\begin{array}{l}\text { Escherichia coli } \\
\text { O157: H7 }\end{array}$ & $\begin{array}{c}\text { Staphylococcus aureus } \\
\text { ATCC } 25923\end{array}$ & $\begin{array}{c}\text { Listeria monocytogenes } \\
\text { CFSAN004330 }\end{array}$ \\
\hline Isolate LAB & $21.26 \pm 0.03$ & $18.23 \pm 0.01$ & $5.10 \pm 0.01$ \\
\hline Penicillin10 $\mu \mathrm{g}$ & $2.70 \pm 0.03$ & - & - \\
\hline Ampicillin $10 \mu \mathrm{g}$ & $14.19 \pm 0.05$ & $21.26 \pm 0.02$ & - \\
\hline Kanamycin $30 \mu \mathrm{g}$ & $16.21 \pm 0.09$ & $13.18 \pm 0.05$ & $10.15 \pm 0.08$ \\
\hline
\end{tabular}

Note: The value is expressed as the mean \pm standard deviation; $n=3$

However, as a whole in Figure 3, it can be seen that bekasam isolate from the stain has antimicrobial activity against all pathogenic bacteria, compared with penicillin which does not inhibit growth of S. aureus ATCC 25923 and L. monocytogenes CFSAN004330 and kanamycin had no antimicrobial activity to $L$. monocytogenes CFSAN004330. Desniar (2012) states that the antimicrobial test against the BALs of tilapia extracts has the ability to inhibit five types of pathogenic bacteria: $E$. coli, S. typimurium ATCC 14028, Bacillus aureus, $S$. aureus, and L. monocytogenes. The results showed that inhibited zones on pathogenic bacteria had high antimicrobial activity. Pan et al (2009) state that the diameter of the inhibited zone against $0-3 \mathrm{~mm}$ pathogenic bacteria showed low antimicrobial activity that is $>3-6 \mathrm{~mm}$ medium antimicrobial activity and $>6 \mathrm{~mm}$ had high antimicrobial activity. Liasi et al. (2009) stated the antagonistic effect of antibacterial compounds on grampositive and gram-negative pathogenic microbial bacteria, such as E. coli, L. monocytogenes, Salmonella enterica, Staphylococcus aureus, and Bacillus cereus.

The same result is also shown by Saithong et al. (2010), using $L$. reuteri IFRDP P17 in Plaa-som, a typical Thai fish fermentation product, capable of suppressing growth, but in contrast with Desniar et al. (2013), which states that isolate LAB from exteriors from Indralaya, Ogan Komiring Ilir (South Sumatra) and Indramayu (West Java), the largest activity of lactic acid bacteria antimicrobials was against $S$. aureus. Lactic acid bacteria were the dominant bacteria found in fermented fish products (Olympia et al. 1992;
Ostergaard et al. 1998). Melia, et al. (2017) states that adding lactic acid bacteria is able to inhibit $L$. monocytogenes. It can also inhibit S. aureus ATCC 25923 (Melia, et al. 2018). The main role of lactic acid bacteria is to ferment carbohydrates that produce organic acids, which can lead to a decrease in $\mathrm{pH}$. The low $\mathrm{pH}$ and presence of organic acids, the main is lactic acid, is a major factor in the process of preservation in fermented fish products. Generally, $\mathrm{pH}$ between 4.5-5.0 can inhibit pathogenic bacteria and decomposers (Owen and Mendoza, 1985). Organic acid produced by Lactic Acid Bacteria has antibacterial activity (Theron and Ludes 2011). Deatraksa et al. (2018) have isolated and identified weissella strains from Thai fermented fish (Plaa Som Fug) which produces antibacterial and folate compounds.

\section{Antimicrobial activity of crude bacteriocin supernatant}

The measurement of antimicrobial activity of isolates Bekasam crude bacteriocin supernatant was obtained after neutralizing $\mathrm{pH}$ in the supernatant of lactic acid bacteria, so that the antimicrobial activity of organic acid was not present. According to Palludan-Muller et al. (2002), components of organic acids, especially lactic acid is the main components of the antimicrobial compounds of lactic acid bacteria. The results of the study can be seen in Table 2 that showed antimicrobial activity after $\mathrm{pH}$ of the lactic acid bacterial supernatant was neutralized to the $E$. coli O157: H7 was $14.99 \mathrm{~mm}$ and S. aureus ATCC25923 that was $17.69 \mathrm{~mm}$ (Figure 4), but defention activities were not shown to L. monocytogenes CFSAN004330.

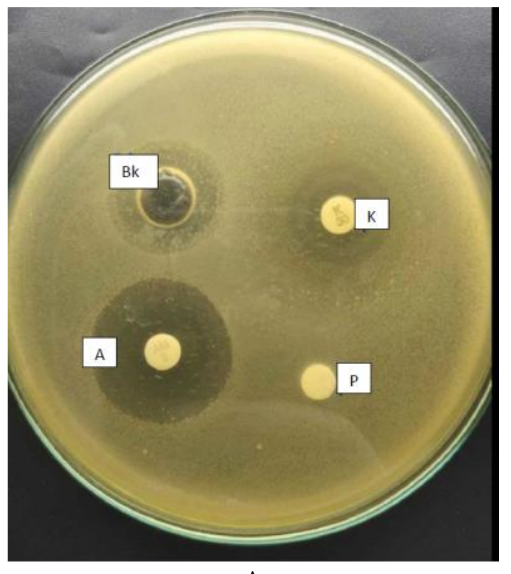

A

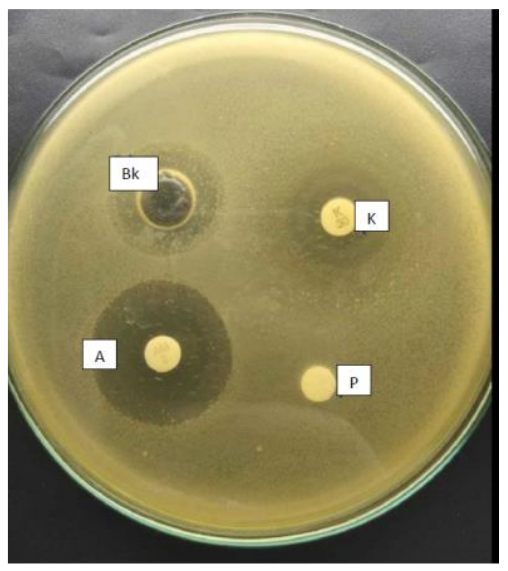

B

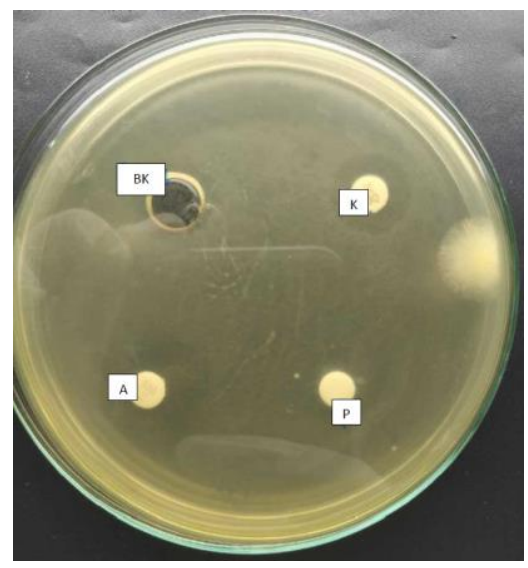

C

Figure 3. Antimicrobial activity of bekasam isolates to E. coli O157: H7 (A), S. aureus ATCC 25923 (B) and L. monocytogenes CFSAN004330 (C). (Note: Bk = Isolate LAB Bekasam, A = Ampicillin, $\mathrm{K}=$ Kanamycin, and P = Penicillin) 


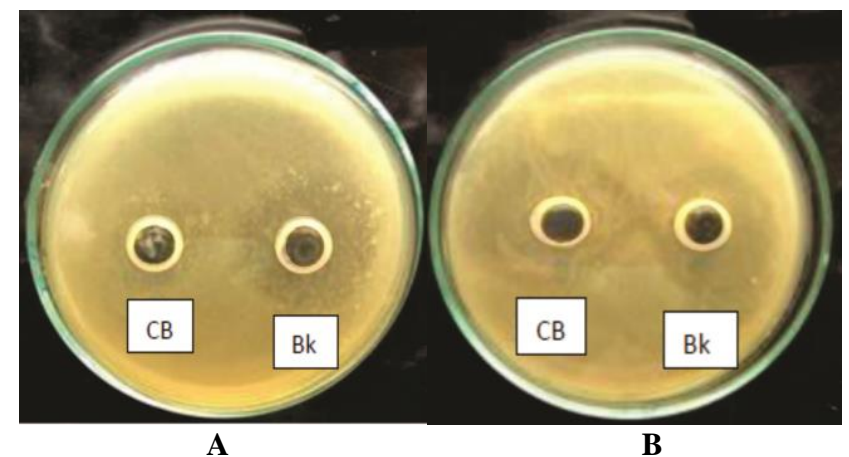

Figure 4. Antimicrobial activity of crude bacteriocin after neutral $\mathrm{pH}(\mathrm{CB})$ and before neutral $\mathrm{pH}(\mathrm{Bk})$ against E. coli O157: H7 (A), against $S$. aureus ATCC 25923 (B)

Table 2. Antimicrobial activity of bekasam isolate crude bacteriocin supernatant

\begin{tabular}{lc}
\hline \multicolumn{1}{c}{ Pathogenic bacteria } & $\begin{array}{c}\text { Diameter clear zone } \\
(\mathbf{m m})\end{array}$ \\
\hline E. coli O157: $\mathrm{H} 7$ & $14.99 \pm 0.03$ \\
S. aureus ATCC 25923 & $17.69 \pm 0.01$ \\
L. monocytogenes CFSAN004330 & - \\
\hline
\end{tabular}

Note: The value is expressed as the mean \pm standard deviation; $n=3$

The result was higher than Melia, et al. (2018) study. In their study, the crude bacteriocin LAB isolates activity from bekasam was against S. aureus ATCC 25923 (13.1 $\mathrm{mm})$ and E. coli O157: $\mathrm{H} 7(12.7 \mathrm{~mm})$. Whereas in the Desniar et al. (2013), LAB isolates from bekasam did not have antimicrobial activity after supernatant $\mathrm{pH}$ was neutralized so that it was thought, antimicrobial activity originated from organic acids produced by lactic acid bacteria. Furthermore, Desniar et al. (2016) isolated $L$. plantarum NS (9) from Bekasam Tilapia Atin that produced antibacterial activity from organic acids. The highest antibacterial activity against E. coli, B. cereus and $L$. monocytogenes at the end of the exponential growth phase (12-15 hour incubation) while $S$. aureus and $S$. typhimurium ATCC 14028 on the $21^{\text {st }}$ and $24^{\text {th }}$ incubation hours.

Furthermore, Fall et al. (2018), revealed that the antimicrobial activity of supernatant cell-free culture from Lactobacillus plantarum and L. brevis isolated from fermented fish meat (guedj) in Senegal was able to inhibit E. coli and L. monocytogenes. Srionnual et al. (2007), found that Weissellicin 110, a class II bacteriocin produced by Weissellicin 110 isolated from Pla-som was able to inhibit gram-positive bacteria, but did not have antimicrobial activity against Listeria monocytogenes. Nurhikmayani et al. (2010), crude bacteriocin from lactic acid bacteria was isolated from Chao, against $S$. aureus FNCC0047 and E. coli FNCC0049.

According to Islam et al. (2012), there are several mechanisms to inhibit the destruction of target cells by bacteriocins. Basically inhibiting the formation of lipids II (cell wall precursors) can be done by following mechanism L a. Inhibition of cell wall biosynthesis, b. Stabilize the formation of membrane target pores. Added by Bahar, and Ren (2013), and Song and Zheng (2015)that when the peptide attaches the target cell membrane, the positive end of the peptide will bind the fatty acids in the phospholipid layer on the target bacterial membrane. This stage involves binding the peptide with a membrane-like a monomer, so that separation occurs that leads to the formation of pores, ultimately causing death in the cell.

\section{Results of 16S rRNA gene amplification by PCR}

In Figure 5, it can be seen that the amplification of the area of the 16S rRNA gene isolates lactic acid bacteria from bekasam. It can be seen by the appearance of PCR fragment of size 1542 bp using R Primer (16S-1492R, Tm $47^{\circ} \mathrm{C}, 5^{\prime}$-GTT TAC CTT GTT ACT ACT-3') and F (16S27F, Tm 54.3 ${ }^{\circ} \mathrm{C}, 5^{\prime}$-AGA GTT TGA TGCC CTC AG$\left.3^{\prime}\right)$ (Doi et al. 2013).

Phylogenetic trees based on $16 \mathrm{~S}$ rRNA gene sequence analysis can be seen in Figure 6. Sequencing results of bekasam isolates compared to Gene Bank data using the BLAST program on the NCBI website (http://www.ncbi.nlm.nih.gov) showed a similarity rate of 99\% with PB22 strain Pediococcus acidilactici, so it can be concluded that the lactic acid bacteria isolate from bekasam isolate is $P$. acidilactici strain PB22. This isolate lactic acid bacteria is a new strain found in bekasam or other fermented fish.

Afriani et al. (2015), isolated lactic acid bacteria from Bekasam from Jambi, which also has proteolytic activity, namely Lactobacillus pentosus BS15, Lactobacillus plantarum 1 BS22 e Lactobacillus plantarum 1 BL12. Nurhikmayani et al. (2019), found Lactobacillus plantarum and Pediococcus pentosaceus from Chao fermented fish from South Sulawesi using 16S rRNA.

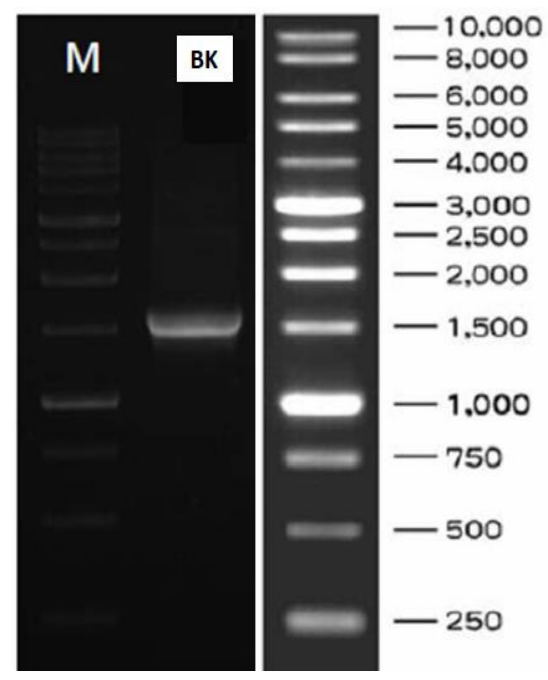

Figure 5. The PCR amplification of ribosomal RNA gene using $11492 \mathrm{R}$ and 27F. BK is isolated lactic acid bacteria bekasam. ( $\mathrm{M}=1 \mathrm{kB}$ DNA Ladder) 


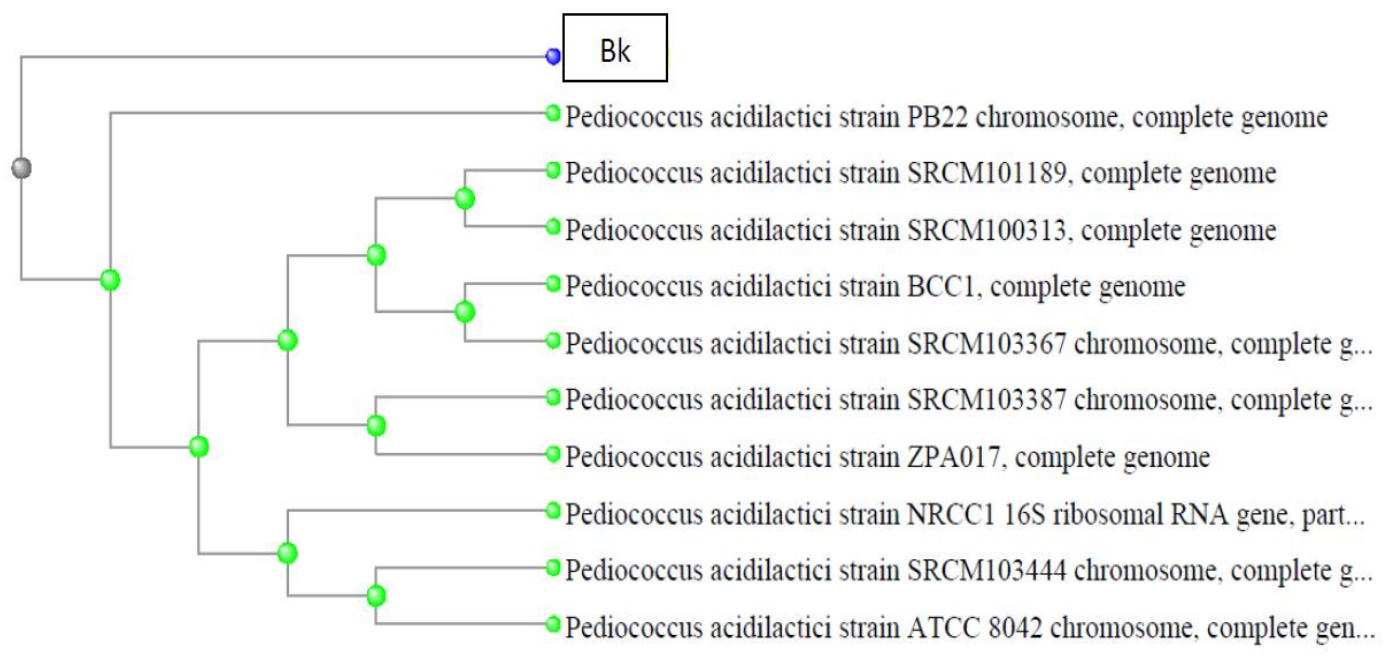

Figure 6. Phylogenetic isolate of lactic acid from bekasam (Bk) (Neighbor-Joining tree-1000x bootstrap)

In addition there are also several sources of lactic acid bacteria from Thai Plaa-som fermented fish products such as Pediococcus pentosaceus, Lactobacillus alimentarius/ farciminis, Weisella confusa, L. plantarum and Lactococcus garviae from Plaa-som, fermented fish products from local producers in Songkhla province, Southern Thailand (Paludan-Mu"ller et al. 2002), Lactococcus garvieae, Streptococcus bovis, Weissella cibaria, Pediococcus pentosaceus, Lactobacillus plantarum, and Lactobacillus fermentum (Kopermsub and Yunchalard 2010), Lb. plantarum and Pediococcus pentosaceous (Nicomarat et al. 2018).

In summary, the results of molecular identification with 16S rRNA showed the potential lactic acid bacteria ( bekasam isolate) as antimicrobial isolation from Bekasam from South Sumatra Banyuasin was similarity with $P$. acidilactici strain PB22. $P$. acidilactici strain PB22, is the new strain found in bekasam. Furthermore, $P$. acidilactici can later be used biopreservatives.

\section{ACKNOWLEDGEMENTS}

This research was supported by research cluster publications to professors (Project T/6/UN.16.17/PP-KPKRP2GB/LPPM/2019) LPPM Universitas Andalas, Padang, Indonesia.

\section{REFERENCES}

Afriani, Arnim, Marlida Y, Yuherman. 2017. Antibacterial Potential of Proteolytic Lactic Acid Bacteria from Bekasam as Beef Biopreservatif. Jurnal Peternakan Indonesia 19 (3): 161-169. [Indonesian]

Ahmad A, Yap WB, Kofli NT, Ghazali AR. 2018. Probiotic potentials of Lactobacillus plantarum isolated from fermented durian (Tempoyak), a Malaysian traditional condiment. Food Sci. Nutr. 6 (6): 1370-1377. DOI: $10.1002 / \mathrm{fsn} 3.672$

Bahar AA, Ren D. 2013. Antimicrobial peptides. Pharmaceuticals 6: 1543-1575.

Deatraksa J, Sunthornthummas S, Rangsiruji A, Sarawaneeyaruk S, Suwannasai N, Pringsulaka O. 2018. Isolation of folate-producing
Weissella spp. from Thai fermented fish (Plaa Som Fug). LWT Food Science and Technology 89: 388-391 DOI: 10.1016/j.lwt.2017.11.016

Desniar I, Rusmana, Suwanto A, Mubarik NR. 2013. Characterization of lactic acid bacteria isolated from an Indonesian fermented fish (bekasam) and their antimicrobial activity against pathogenic bacteria. Emir J Food Agric 25 (6): 489-494. DOI:10.9755/ejfa

Desniar I, Rusmana, Suwanto A, Mubarik NR. 2012. Antimicrobial compounds produced by the former lactic acid bacteria Bekasam. J. Akuatika 3:135-145. [Indonesian]

Desniar I, Setyaningsih, Purnama YI. 2016. Screening and production of antibacterial from Lactobacillus plantarum NS (9) Isolated from Nile Tilapia Bekasam. Jurnal Pengolahan Hasil Perikanan Indonesia 19 (2): 132-139. [Indonesian]

Doi K., Phuong OTA, Kawatou F, Nagayoshi Y, Fujino Y, Ohshima T. 2013. Identification and characterization of lactic acid bacteria isolated from fermented rice bran product. Adv Microbiol 3: 265-272. DOI: 10.4236/aim.2013.33038

Fall NG, Diop MB, Tounkara LS, Thiaw OT, Thonart P. 2018. Characterization of bacteriocin-like producing lactic acid bacteria (LAB) isolated from the crude and traditionally fermented fish meat (guedj) in Senegal. Intl J Fish Aquacult Res 4 (3): 26-35.

Hamzah B. 2016. The use of water seal fermentor in fish fermentation of bekasam. Adv J Food Sci Technol 10 (3): 202-203.

Hartini P, Purwanto H, Juliyarsi I, Yuherman, Purwati E. 2019. Probiotic potential of lactic acid bacteria Lactobacillus fermentum NBRC 15885 isolation from tempoyak in Padang Pariaman District, West Sumatra (Indonesia) to acid condition, bile salts and antimicrobial activity. Intl Res J Pharm 10 (3): 70-73. DOI: 10.7897/22308407.100381

Islam MR, Nagao JI, Zendo T, Sonomoto K. 2012. Antimicrobial mechanism of lantibiotics. Biochem Soc Trans 40 (6): 1528-1533. DOI: 10.1042/BST20120190

Juliyarsi I, Purwati E, Hartini P, Yuherman, Djamaan A, Arief, Purwanto H, Aritonang SN, Hellyward J. 2018. Characterization of lactic acid bacteria and determination of antimicrobial activity in tempoyak from Padang Pariaman District, West Sumatra, Indonesia. Pak. J. Nutr 17 (10): 506 to 511. DOI: $10.3923 /$ pjn.2018.506.511

Liasi, SA., Azmi TI, Hassan MD, Shuhaimi M, Rosfariza, Ariff AB. 2009. Antimicrobial activity and antibiotic sensitivity of three isolates of lactic acid bacteria from fermented fish product, Budu. Malaysian Journal of Microbiology 5(1): 33-37. DOI: 10.21161/mjm.15008

Melia S, Suryanto D, Yurnaliza. 2018. Antimicrobial activity of lactic acid bacteria isolated from bekasam against Staphylococcus aureus ATCC 25923, Escherichia coli ATCC 25922, and salmonella sp. IOP Proc Earth Environ Sci. DOI:10.1088/1755-1315/130/1/012011 
Melia S, Yuherman, Jaswandi, Purwati E, Aritonang S and Silaen M. Characterization of the Antimicrobial Activity of Lactic Acid Bacteria Isolated from Buffalo Milk in West Sumatra (Indonesia) Against Listeria monocytogenes. Pak J Nutr 16 (8): 645-650. DOI: 10.3923/pjn.2017.645.650

Melia S, Yuherman, Jaswandi, Purwati E. 2018. Selection of buffalo milk, lactic acid bacteria with probiotic potential. Asian J Pharmaceut Clin Res 11 (6): 186-189. DOI: 10.22159/ajpcr.2018.v11i6.24809

Nicomrat D, Lakthandee M, Suenonmueng N, Marjang N. 2018. Lactic acid bacteria starter participating in hygienic long shelf-life of the plaa-som fermented product. Appl Mechanics Materials 879: 113117. DOI: $10.4028 /$ www.scientific.net/AMM.879.113

Nurhikmayani R, Daryono BS, Retnaningrum E. 2019. Isolation and molecular identification of antimicrobial-producing Lactic Acid Bacteria from chao, South Sulawesi (Indonesia) fermented fish $\begin{array}{lllll}\text { product. } & \text { Biodivesitas } 20 & \text { (4): 1063-1068. DOI }\end{array}$ 10.13057/biodiv/d200418

Olympia M, Ono H, Shinmyo A, Takano M. 1992. Lactic acid bacteria in a fermented fishery product, burong bangus. J. Ferment. Bioeng 73: 193-197. DOI: 10.1016/0922-338X (92)90159-R

Ostergaard A, Embarek B, Yamprayoon PK, Wedell-Neergaard J, Huss C, Gram L. 1998. Fermentation and spoilage of som-fak, a Thai low-salt fish product. Trop Sci 38: 105-112.

Owens JD, Mendoza LS. 1985. Enzymatically hydrolysed and bacterially fermented fishery products. J Food Technol 20:273-293. DOI 10.1111/j.1365-2621.1985.tb00378.x

Paludan-Mu“ller C, Madsen M, Sophanodora P, Gram L, Mø ller PL. 2002. Fermentation and microflora of plaa-som, a Thai fermented fish product prepared with different salt concentrations. Intl J Food Microbiol 73:61-70. DOI: 10.1016/s0168-1605 (01)00688-2

Pan X, Chen F, Wu T, Tang H, Zhao Z. 2009. The acid, bile tolerance and antimicrobial property of Lactobacillus acidophilus NIT. Food Control 20: 598-602. DOI: 10.1016/j.foodcont.2008.08.019

Phikunthong K, Yunchalard S. 2010. Identification of lactic acid bacteria associated with the production of plaa-som, a traditional fermented fish product of Thailand. Intl J Food Microbiol 138: 200-204. DOI: 10.1016/j.ijfoodmicro.2010.01.024

Saithong P, Panthavee W, Boonyaratanakornkit M, Sikkhamondhol C. 2010. Use of a starter culture of lactic acid bacteria in plaa-som, a
Thai fermented fish. J Biosci Bioeng 110 (5): 553-557. DOI: 10.1016/j.jbiosc.2010.06.004

Song H, Zheng W. 2015. Antimicrobial natural products the battle against microbial pathogens: basic science, technological advances and educational programs In: Me'ndez-Vilas A (ed.). The battle against microbial pathogens: basic science, technological advances and educational programs, 1 st ed. Formatex Research Center, Spain.

Srionnual S, Yanagida F, Li-Hsiu L, Kuang-Nan H, Yi-sheng C. 2007. Weissellicin 110, a newly discovered bacteriocin from Weissella cibaria 110 , isolated from plaa-som, a fermented fish product from Thailand. Appl Environ Microbiol 73 (7): 2247-2250. DOI:10.1128/AEM.02484-06

Surono IS. 2003. In vitro probiotic properties of indigenous dadih lactic acid bacteria. Asian-Australasian J Anim Sci 16 (5):726-731. DOI: 10.5713/ajas.2003.726

Surono IS, Pato U, Koesnandar, Hosono A.2009. In vivo Antimutagenicity of Dadih Probiotic Bacteria towards Trp-P1. AsianAust. J. Anim. Sci. 22(1):119-123. DOI: 10.5713/ajas.2009.80122

Theron MM, Lues JFR. 2011. Organic Acids and Food Preservation. CRC Press, United States.

Venema K, Surono IS. 2019. Microbiota composition of dadih-a traditional fermented buffalo milk of West Sumatra. Lett Appl Microbiol 68 (3): 234-240. DOI:10.1111/lam.13107

Wikandari P, Suparmo R, Yustinus M, Endang SR. 2012. Characterization of proteolytic lactic acid bacteria in the Bekasam. Jurnal Natur Indonesia 14 (2): 120-125. [Indonesian]

Wirawati CU, Sudarwanto MB, Lukman DW, Wientarsih I, Srihanto EA. 2019. Diversity of lactic acid bacteria in dadih produced by either back-slopping or spontaneous fermentation from two different regions of West Sumatra, Indonesia. Vet World 12 (6): 823-829. DOI: 10.14202/vetworld.2019.823-829

Yang E, Lihua F, Yueming J, Craig D, Sherry F. 2012. Antimicrobial activity of bacteriocin producing lactic acid bacteria isolated from cheeses and yogurts. AMB Express (2):48. DOI: 10.1186/2191-0855$2-48$

Yusra F, Azima, Novelina, Periadnadi. 2013. Antimicrobial activity of lactic acid bacteria from budu of West Sumatra to food biopreservative. Pak J Nutr 12 (7): 628-635. DOI: 10.3923/pjn.2013.628.635. 